\title{
Non- invasive functional exploration techniques for bivalves with applications to pearl oyster Pinctada margaritifera
}

\author{
Le Moullac Gilles ${ }^{1,}{ }^{\text {, }}$, Soyez Claude ${ }^{1}$, Lyonnard Pierre ${ }^{1}$, Chabrier Sébastien ${ }^{2}$, Milhade Leo ${ }^{1}$, \\ Gueguen Yannick ${ }^{3}$, Beliaeff Benoit ${ }^{1}$
}

1 Ifremer UMR Ecosystèmes Insulaires Océaniens UPF ILM IRD Taravao Tahiti, Polynésie française

2 Laboratoire GEPASUD Université de Polynésie Française Faa'a Tahiti ,Polynésie française

${ }^{3}$ UMR IHPE Université de Montpellier CNRS Ifremer UPVD Montpellier, France

* Corresponding author : Gilles Le Moullac, email address : gilles.le.moullac@ifremer.fr

\begin{abstract}
:
Non-invasive functional exploration techniques can provide information on different aspects of general organism functioning and, unlike lethal or invasive techniques, allow individual organisms to be monitored for as long as necessary. For bivalves, a fairly wide variety of methods and instrumental means exist allowing physiology to be assessed on-line while keeping animals alive and intact. The current range of non-invasive techniques for bivalves consists of systems for measuring metabolic flows and valve activity, which can be used on bivalve molluscs for as long as an individual animal's characteristics (e.g. size) make this technically feasible. In this paper, we present some of these non-invasive techniques with applications for pearl oyster and list other potentially promising techniques. We also focus on a unique method we developed specifically for to record the pearl rotation characteristics within pearl oysters. This article presents the state of the art in non-invasive functional exploration techniques. We hope that the information provided here will be useful to physiologists of bivalve marine molluscs through the tools and applications presented here or other future approaches based on them.
\end{abstract}

Keywords : bivalve, filtration, pearl rotation, respiration, valvometry 


\section{Introduction}

The pearl oyster Pinctada margaritifera is a marine bivalve with a distribution range in the intertropical zone of the Pacific and Indian Oceans. This species is exploited, mainly in French Polynesia, for the production of cultured pearls. For many years this species has been the subject of studies aiming to improve knowledge of its nutritional needs (Le Moullac et al., 2013; Vahirua-Lechat et al., 2008), reproduction (Chávez-Villalba et al., 2011; Teaniniuraitemoana et al., 2015, 2014) and mechanisms controlling biomineralization (Blay et al., 2018; Joubert et al., 2014, 2010; Le Luyer et al., 2019). Beyond the acquisition of purely biological knowledge, $P$. margaritifera is studied for the improvement of pearl production (Gueguen et al., 2013) and its potential to adapt to environmental challenges (Beliaeff et al., 2017). Ecophysiological approaches make it possible to study and model the behavioural and physiological responses of pearl oysters to their environment over their development, and can be based on non-invasive exploration techniques. In contrast to invasive techniques, non-invasive functional exploration allows individual organisms to be monitored as long as necessary. Such non-invasive experimental approaches can provide information on the general functioning of organisms. For bivalves, there is a fairly wide variety of methods and instrumental means allowing on-line physiological assessment of intact animals. The current range of non-invasive techniques for bivalves includes systems for measuring metabolic flows (filtration, respiration) and valve activity that can be applied to the bivalve molluscs as long as the animal characteristics (e.g. size) make this technically feasible. In this paper we present those non-invasive techniques with applications to pearl oyster, and list other potentially promising approaches. We also focus on a unique method that we developed specifically for the pearl oyster to record pearl rotation characteristics.

\section{Measuring metabolic fluxes}

In living organisms, the measurement of ecophysiological parameters of nutrition and respiration makes it possible to establish an energetic balance of assimilated organic matter. In bivalves, this balance is generally expressed as a growth potential including reproduction, known as "Scope For 
Growth, SFG" (Bayne, 1976). Based on ecophysiological functions such as filtration, consumption, absorption and respiration, which are known to vary according to the environment, the energy balance provides an "estimate" of the physiological status of the animal at different periods of its development and according to the environmental parameters. More precisely, the calculation of an organism's energy balance consists in drawing up a balance of energy gains and losses, assuming that the amount of energy acquired through food during assimilation is used for maintenance, growth and reproduction. The energy balance calculation is more accurate when filtration and respiration measurements are carried out on the same animals, in the same enclosure.

Measurements of bivalve ingestion and respiration allow an energy balance to be established, providing indications about the relationship of these animals with their living conditions. In our ecophysiological measurement system (EMS) (Figure 1a) (Chávez-Villalba et al., 2013), energy flows can be measured in an, which is composed of eleven open-flow chambers. In our experiments ten oysters are placed in ten of the chambers and the remaining eleventh chamber is left empty to serve as a control. The drains of the chambers are each equipped with a two-way electromagnetic valve activated by an automaton. When the valve of one measuring chamber is opened, the released water is analyzed for 3 min using a 10AU fluorometer (Turner, USA) and an oximeter (OXI 358, WTW, Weilheim, Germany) to measure the fluorescence and dissolved oxygen. The measurements of each chamber are carried out by piloting 11 electrovans, which successively remove part of the effluent to the sensors (oximeter, fluorimeter). A National Instrument (NI) Ethernet cFP-2120 network module is controlled by a real-time LabView (NI) driver. The card transmits data and tracking graphs via Ethernet on an interface (figure $1 \mathrm{~b}$ ) that provides the values of incoming flows, sampling by successive opening and closing of the electrovans, real-time display of all curves (fluorescence of microalgae, dissolved oxygen, flows), and recording of average data on the computer dedicated to EMS management. Each cycle is completed within $3 \mathrm{~min}$ and another cycle then starts in the control chamber and lasts 3 min (sequence: chamber 1, control, chamber 2, control, etc.). The specimens remain in the chambers for $48 \mathrm{~h}$ and measurements can be taken every 60 min until 48 fluorescence 
and oxygen measurements have been recorded. The respiration rate (RR), expressed in $m g \mathrm{O}_{2} \mathrm{~h}^{-1}$, is estimated by the difference in the oxygen concentration between the control and experimental chambers using the following formula: $\mathrm{RR}=\mathrm{V}(\mathrm{O} 1-\mathrm{O} 2)$, where $\mathrm{O} 1$ is the oxygen concentration in the control chamber, $\mathrm{O} 2$ the oxygen concentration in the experimental chamber, and $\mathrm{V}$ the water flow rate. Ten measurement series are commonly performed on groups of four pearl oysters, each composed of two grafted and two non-grafted pearl oysters. The energy expenditure is expressed as RR of individuals (total energy expenditure) and as standardized RR (Savina and Pouvreau, 2004).

Replicates from EMS thus make it possible to accurately estimate the energy status of the bivalves under various environmental pressures or according to their physiological status and/or genetics. Measurements are taken on individuals who have previously been acclimatized for at least one month in a contiguous room with $8500 \mathrm{~L}$ tanks also equipped with environmental control systems. This experimental tool allowed us to show that the oxygen requirement of female $P$. margaritifera is higher than that of males (Chávez-Villalba et al., 2013). The energy balance of the species was also measured at different temperatures to calculate its thermal optimum and to estimate the energy risk of climate warming (Le Moullac et al., 2016a); this also demonstrated that acidification has no significant impact (Le Moullac et al., 2016b). The effect of anthropogenic environmental pressures such as microplastics has been studied and we have thus been able to determine that the bioenergetic response is dose-dependent (Gardon et al., 2018). Finally, we observed that pearl oysters grafted for the production of cultured pearls did not expend significatively more energy, as estimated by oxygen consumption, than the non-grafted ones. We could therefore inferred that the energy cost associated with pearl formation is negligible (Le Moullac et al., 2018b).

\section{Measuring pearl rotation}

Cultured pearls are produced by first making a grafting operation, during which a small piece of mantle tissue from a donor oyster (the graft) is inserted in the gonad of the recipient oyster together with a nacre bead, the nucleus (Wada, 1999). Once positioned in the recipient oyster, the outer 
epithelium cells of the graft multiply and form a pearl sac around the nucleus. The pearl sac then starts to deposit nacre (aragonite) layers onto the nucleus. This is the starting point of the future pearl. A rearing period of approximately 18 months is then needed to produce a pearl with a sufficiently thick layer of nacre for the market (Gueguen et al., 2013). A pearl is round for at least two reasons: (i) because the nucleus is spherical and (ii) the growth front of nacre on the surface of the pearls suggests that rotation is taking place. Cartwright et al. (2013) put forward a theory of pearl rotation, explaining how forces acting during the deposition of aragonite tablets would lead to a particular type of pearl movement. The layers of aragonite oriented in specific directions on the surface would give momentum to the pearl during the growth of its layers, thus causing movement. Once activated, a dynamic mechanism would be initiated that could lead to different rotational movements, particularly depending on whether the pearl has a defect. We were finally able to develop an unique device to make demonstrate that the pearl rotates during its formation in the pearl sac of the pearl oyster Pinctada margaritifera (Gueguen et al., 2015).

The magnetometer used in this study is made up of three main connected parts. The measuring part is a dome with sensors consisting of a half-sphere of acrylic glass (diameter $20 \mathrm{~cm}$ ) on which are set 25 magnetic sensors each consisting of two components (figure 2), an HMC1021 compass from Honeywell (a one-axis magnetic sensor) and an offset compensation circuit. Twenty-four of the 25 sensors are spread across the convex surface of the dome in three circles of eight elements at $0^{\circ}, 30^{\circ}$ and $60^{\circ}$ angles with the base. The last sensor is located at the top of the dome at $90^{\circ}$. Each sensor is glued on the dome with a cyanoacrylate paste and protected from impacts and water by an acrylic glass tube. The electrical part of the magnetometer is composed of a data acquisition board with 26 RJ45 sockets ( 25 used to connect the cables from the sensors and the last one to make the ethernet connection with the computer) and 25 wiring cables, each of which ends in a RJ45 plug. The HumanMachine Interface (HMI) is a program called "magneto", developed by VEGA Industrie (Avrainville, France), which is composed of two parts. The first part of the HMI is a microcontroller that uses internal software to collect, process and transfer data to the second. This second part is software on 
the computer (magneto-magnetometer interface 1.0), which collects data from the microcontroller, allows data to be collected from real time sensors and produces visualized data, thus tracking the acquisition process. This interface is used to define communication, data acquisition parameters and to make backups. The following parameters were defined for our experiments: acquisition frequency: 50 (1/10s); filtration rate: 5 ; recording periodicity: 1 minute. The export data file is a .CSV file, which the software names with references to the date and hour of start: Magneto_YYYY_MM_DD_HH_MM.csv. The data acquired by the magnetometer were processed with an $\mathrm{R}$ routine to convert the data acquired into $3 \mathrm{D}$ coordinates and perform calculations on pearl movement kinetics. Mean angular speed of rotation $\left(\mathrm{min}^{-1}\right)$ and a graphical representation determining the type of pearl motion could then be derived from the converted data (figure 3).

The experiment carried out using this device showed that the pearl actually turns in the pearl sac, with rotation starting as soon as the pearl sac closes (Gueguen et al., 2015). The pearl sac is the result of the development of cells of the graft that was implanted during the grafting operation, at the same time as the nucleus. The healing of the gonad and development of the pearl sac take time. It is estimated that the pearl sac becomes functional - i.e., the first aragonite deposits are observed between 30 and 45 days after the transplant operation. This was confirmed by rotational recordings using a magnetometer in pearl oysters grafted with magnetized nuclei (Gueguen et al., 2015).

Once the rotation of pearls was demonstrated, the question of most interest to the industry was the link between rotation and formation, and hence quality, of pearls. We first showed that rotation speed differed according to the type of movement: pearls with axial movement had a significantly higher rotation speed than those with random movement (Le Moullac et al, 2018a). When we conducted ecophysiological experiments to test the impact of the environment on pearl rotation and formation, however, we found pearl growth rate to be influenced by temperature but not by pearl rotation speed. On the basis of our results, we now consider pearl rotation to be a more complex process than formerly thought. Mechanisms involved could include strong environmental forcing in 
immediate proximity to the pearl. Another implication of our findings is that, in the context of ocean warming, pearl growth and quality can be expected to decrease in pearl oysters exposed to temperatures above $30^{\circ} \mathrm{C}$ (Le Moullac et al., 2018a).

\section{Measuring valve activity}

Bivalve valve behaviour is a potentially important tool for biological monitoring of water quality as, through these movements, bivalves can serve as environmental sentinels (Borcherding, 2006). Valve activity is also essential for understanding metabolism optimization strategies. A relatively large number of methods exist for observing and measuring valve movement, as presented below.

A strain gauge can be used to record valve movements of oysters. Composed of electrically resistant wires, it converts the stretching of these wires into variations in electrical resistance. Strain gauges are cemented onto thin, flexible strips of metal that are attached to a nylon line. This line is cemented onto the upper valve of the oyster. A system of this type (BLH Electronics, Waltham, Mass., U.S.A.) was developed to measure shell-valve gape activity and periodic activity of Crassostrea virginica (Higgins, 1980). It was later applied to mussels following their exposure to the toxic dinoflagellate Protogonyaulax tamarensis (Shumway and Cucci, 1987). Subsequently, Porter and Breitburg (2016) developed a comparable system (SG13/1000-LY43 or LY41, Omega Engineering Inc., Stanford, Connecticut) directly sealed onto the shells for gape monitoring of $C$ virginica under dielcycling hypoxia.

An inductance-based valvometry device was constructed to study the valve rhythm dynamics of Corbicula fluminae when exposed to copper (Jou et al., 2016). This device was conceived by attaching a pair of lightweight electrical coils to the valves and using them as sensors to determine the degree of bivalve opening. This system makes it possible to record the valve behaviour of several bivalves simultaneously. An interface card (NI DAQPad-6259) controls the acquisition of the corresponding signals, and a specific LabVIEW program monitor compiles data. This way, valve activities of clams were recorded dynamically in real time. 
The HFNI valvometer is a high frequency (10 Hertz), non-invasive (HFNI) biosensor. The animal is equipped with two light coils (sensors), $\approx 53 \mathrm{mg}$ each (unembedded), fixed on the edge of each valve. These coils are coated with a resin-sealing before fixation to the valves. One of the coils emits a highfrequency sinusoidal signal that is received by the other coil. Each animal's behaviour is thus measured every $1.6 \mathrm{~s}$ (Andrade et al., 2016; Sow et al., 2011).

Gaping activity is measured using magnetoresistive sensors (Honeywell). The sensor is formed by four encapsulated reeds activated by a magnet, and the supports glued onto each valve. The magnet is also encapsulated, with the reeds and slides hanging on it attached to two stainless steel rods of 1 $\mathrm{mm}$ diameter and $10 \mathrm{~cm}$ long (Garcia-March et al., 2016).

In our laboratory, a type of electromagnetic valvometer was tested. This is an automatic and continuous recording device of bivalve valve movements designed according to the Hall Effect Principle (1879), which states that an electric current passing through a material bathed in a magnetic field generates a voltage perpendicular to the latter. The valvometer ( "Mémocollecteur" developed by Micrel, Hennebont, Morbihan), described by Floch (1994), takes the form of cylindrical structure of approximately $300 \mathrm{~mm}$ in diameter, with a maximum height of $50 \mathrm{~mm}$ and a mass of 2 kg. Between 4 and 8 bivalves are fixed horizontally in the periphery on a PVC crown, while the centre of the device contains an autonomous miniaturized data acquisition microprocessor. The PVC blades come out from a receptor, and reach onto the top valve of the oysters, opposite the hinge. An adjustable vinyl tip adjusts the sensor position when the oyster is closed. When the oyster opens, the tip lifts the PVC blade. The gap between the stem and the central receptor thus increases. An electromagnet located in this receptor transforms this gap into an electrical signal.

When the signal is part of a time series (figure 4), spectral analysis can reveal the rhythms of activity. In our study, spectral analysis of the record series of the valved activity revealed a period of $23.25 \mathrm{~h}$ and a lower density of $2.15 \mathrm{~h}$ (figure $5 \mathrm{a}$ ), followed by a set of repetitive high-frequency and lowamplitude micro-movements (figure 5b). These micro-movements are interesting because they were 
almost perpetual. These micromovements could be one of the engines of filtration, in addition to the ciliary activity of the gills. Correspondingly, we can now hypothesize that these valve micromotions are involved in the rotation of beads in grafted pearl oysters. This hypothesis should be tested by simultaneously measuring the valve activity and the rotation of the bead at the same frequency (per second). In P. margaritifera, the records of pearl oyster valve opening variations over 15 days in the lagoon of Takapoto in 1995 (Buestel, unpublished data) revealed a marked diel cycle. Oysters open more, and thus filter more, at night than during the day.

The valvometers put out an electrical signal $(\mathrm{mV})$ that is used in a binary manner (open/closed), together with the opening time (Jou et al., 2016; Porter and Breitburg, 2016), or transformed into a spread value $(\mathrm{mm})$. The spread value of the opened valves can be compared when the measurements are standardized; in this case, the opening width $(\mathrm{mm})$ is transformed into the degree of aperture considering the valves as two sides of a right-angled triangle. The spread of the opening is then the measure on the opposite side of the angle, transformed into an aperture angle. Indeed, the height, unlike the angle, depends on the position of the needle on the animal and the animal's length. To eliminate this bias, by likening the oyster to a right-angled triangle (figure 6), it is then possible to calculate: $\sin (\alpha)=H / L$, hence $\alpha=\arcsin (H / L)$. In a previous study (Le Moullac, 2008), this transformation of valve spread values made it possible to measure responses to prolonged hypoxia in Pacific oyster $C$. gigas, which induced a reduction in average valve opening.

\section{Non-invasive methods for future applications}

Measuring cardiac activity could usefully complement the range of different measures described above. Heart rate was successfully used as a proxy for whole-animal stress (Braby and Somero, 2006), in response to toxins (Davenport, 1977; Depledge et al., 1996; Grace and Gainey, 1987; Wedderburn et al., 2000), temperature (Coleman and Trueman, 1971; Helm and Trueman, 1967; Pickens, 1965), salinity (Nicholson, 2002; Stickle and Sabourin, 1979) and predation (Rovero et al., 1999). Two main technical principles are used: impedance and infrared. Impedance, measuring an electrical resistance, can be considered as an invasive technique because it requires drilling into the 
bivalve shell to insert two small electrodes (copper or platinum) into the pericardial cavity. These electrodes are attached to the shell by a surgical glue or dental cement. This method produces an analogue impedance signal, which is converted to a voltage signal (Braby and Somero, 2006; Earll, 1975; Gainey and Shumway, 1988). The method of measuring heart rate (HR) by infra-red (IR) is more recent and non-invasive because it does not require perforation of the shell. A waterproof photoplethysmograph is glued on the shell in the vicinity of the cardiac region, with optical sensors consisting of an infrared transmitter and a phototransistor. Tests of the transmission of an infrared signal through the pearl oyster shell demonstrated the a limitation of the method, however, because the shells of $P$. margaritifera individuals greater than $85 \mathrm{~mm}$ in height are too thick to allow the IR signal through.

Magnetic resonance imaging (MRI), although not greatly used, can provide a very wide range of information that is currently acquired by bivalve dissection. Application of MRI is possible in marine bivalves, especially oysters, with sufficient spatial resolution to depict anatomy without movement artefacts or magnetic susceptibilities (Pouvreau et al., 2006). MRI techniques have been used to characterize gonad development and to determine the sex of live Pacific oysters through their shells (Davenel et al., 2009, 2006). Recent advances in MRI in real time allow us to visualize the movements of organs such as the human heart, tongue, and joints (Uecker et al., 2010; Zhang et al., 2010) (https://www.independent.co.uk/news/health/realtime-mri-live-video-tongue-jens-frahm-maxplanck-institute-european-patent-office-a8327001.html). Applying such technology to the pearl oyster would allow the observation of pearl formation and improve our understanding of the origin of pearl rotation.

\section{Conclusion}

256 MRI exploration can provide regular information for tracking reproduction, through maturation to spawning, and to see the first developments of the pearl sac. The latest advances in MRI, which show

258 the dynamic capabilities of real time MRI, should help to unravel some of the mystery about pearl rotation. Simultaneous non-invasive functional explorations can be considered, combining measures 
of metabolic flux, rotation of pearls, and recording of valve activity, preferentially using stress gauges that would not interfere with the magnetometric system signals. This article reviews the state of the art of non-invasive functional exploration techniques that can be used in bivalves. We hope that this paper will be useful to physiologists of bivalve marine molluscs through the tools and applications presented here or others that could be conceived in the future.

\section{Acknowledgments}

The authors express their gratitude to Bélinda Hui who helped lay down the principles of the magnetometer project and Max Mastail, now retired, who led the design of the magnetometer. We also thank Dominique Buestel for providing the valvometric data. We would also like to thank the entire technical team of the Ifremer Pacific Centre (IMA team) who assembled these unique systems.

\section{References}

Andrade, H., Massabuau, J.-C., Cochrane, S., Ciret, P., Tran, D., Sow, M., Camus, L., 2016. High Frequency Non-invasive (HFNI) Bio-Sensors As a Potential Tool for Marine Monitoring and Assessments. Frontiers in Marine Science 3. https://doi.org/10.3389/fmars.2016.00187

Bayne, B.L., 1976. Aspects of reproduction in bivalve molluscs., in: WILEY, M. (Ed.), Estuarine Processes. Academic Press, pp. 432 - 448. https://doi.org/10.1016/B978-0-12-7518015.50043-5

Beliaeff, B., Le Moullac, G., Saulnier, D., Ky, C.-L., 2017. Perliculture en Polynésie française - Enjeux économiques, scientifiques et techniques. TI base documentaire : TIB140DUO., 18.

Blay, C., Planes, S., Ky, C.-L., 2018. Cultured Pearl Surface Quality Profiling by the Shell Matrix Protein Gene Expression in the Biomineralised Pearl Sac Tissue of Pinctada margaritifera. Marine Biotechnology. https://doi.org/10.1007/s10126-018-9811-y

Borcherding, J., 2006. Ten Years of Practical Experience with the Dreissena-Monitor, a Biological Early Warning System for Continuous Water Quality Monitoring. Hydrobiologia 556, 417-426. https://doi.org/10.1007/s10750-005-1203-4

Braby, C.E., Somero, G.N., 2006. Following the heart: temperature and salinity effects on heart rate in native and invasive species of blue mussels (genus Mytilus). Journal of Experimental Biology 209, 2554-2566. https://doi.org/10.1242/jeb.02259

Cartwright, J.H.E., Checa, A.G., Rousseau, M., 2013. Pearls Are Self-Organized Natural Ratchets. Langmuir 29, 8370-8376. https://doi.org/10.1021/la4014202

Chávez-Villalba, J., Soyez, C., Aurentz, H., Le Moullac, G., 2013. Physiological responses of female and male black-lip pearl oysters (Pinctada margaritifera) to different temperatures and concentrations of food. Aquatic Living Resources 26, 263-271. https://doi.org/10.1051/alr/2013059

Chávez-Villalba, J., Soyez, C., Huvet, A., Gueguen, Y., Lo, C., Le Moullac, G., 2011. Determination of gender in the pearl oyster Pinctada margaritifera. Journal of Shellfish Research 30, 231-240. 
Coleman, N., Trueman, E.R., 1971. The effect of aerial exposure on the activity of the mussels Mytilus edulis L. and Modiolus modiolus (L.). Journal of Experimental Marine Biology and Ecology 7, 295-304. https://doi.org/10.1016/0022-0981(71)90011-6

Davenel, A., Pouvreau, S., Cambert, M., Suquet, M., Mariette, F., 2009. NMR relaxometry as a potential non-invasive routine sensor for characterization of phenotype in Crassostrea gigas. Aquaculture 291, 74-77. https://doi.org/10.1016/j.aquaculture.2009.03.008

Davenel, A., Quellec, S., Pouvreau, S., 2006. Noninvasive characterization of gonad maturation and determination of the sex of Pacific oysters by MRI. Magnetic Resonance Imaging 24, 11031110. https://doi.org/10.1016/j.mri.2006.04.014

Davenport, J., 1977. A study of the effects of copper applied continuously and discontinuously to specimens of Mytilus edulis (L.) exposed to steady and fluctuating salinity levels. Journal of the Marine Biological Association of the United Kingdom 57, 63-74. https://doi.org/10.1017/S0025315400021238

Depledge, M.H., Lundebye, A.-K., Curtis, T., Aagaard, A., Andersen, B.B., 1996. Automated interpulseduration assessment (AIDA): a new technique for detecting disturbances in cardiac activity in selected macroinvertebrates. Marine Biology 126, 313-319. https://doi.org/10.1007/BF00347455

Earll, R., 1975. Temporal variation in the heart activity of Scrobicularia plana (Da Costa) in constant and tidal conditions. Journal of Experimental Marine Biology and Ecology 257-274.

Floch, A., 1994. Un capteur biologique original enregistrant les mouvements valvaires des mollusques bivalves (PhD Thesis). Ecole nationale vétérinaire, Nantes.

Gainey, L.F., Shumway, S.E., 1988. Physiological effects of Protogonyaulax tamarensis on cardiac activity in bivalve molluscs. Comparative Biochemistry and Physiology Part C: comparative pharmacology 159-164.

Garcia-March, J.R., Jiménez, S., Sanchis, M.A., Monleon, S., Lees, J., Surge, D., Tena-Medialdea, J., 2016. In situ biomonitoring shows seasonal patterns and environmentally mediated gaping activity in the bivalve, Pinna nobilis. Marine Biology 163. https://doi.org/10.1007/s00227016-2812-3

Gardon, T., Reisser, C., Soyez, C., Quillien, V., Le Moullac, G., 2018. Microplastics Affect Energy Balance and Gametogenesis in the Pearl Oyster Pinctada margaritifera. Environmental Science \& Technology 52, 5277-5286. https://doi.org/10.1021/acs.est.8b00168

Grace, A.L., Gainey, L.F., 1987. The Effects of Copper on the Heart Rate and Filtration Rate of Mytilus edulis. Marine Pollution Bulletin 87-91.

Gueguen, Y., Czorlich, Y., Mastail, M., Le Tohic, B., Defay, D., Lyonnard, P., Marigliano, D., Gauthier, J.P., Bari, H., Lo, C., Chabrier, S., Le Moullac, G., 2015. Yes, it turns: experimental evidence of pearl rotation during its formation. Royal Society Open Science 2, 150144. https://doi.org/10.1098/rsos.150144

Gueguen, Y., Montagnani, C., Joubert, C., Marie, B., Belliard, C., Tayale, A., Fievet, J., Levy, P., Piquemal, D., Marin, F., Le Moullac, G., Ky, C.-L., Garen, P., Lo, C., Saulnier, D., 2013. Characterization of molecular processes involved in the pearl formation in Pinctada margaritifera for a sustainable development of pearl farming industry in French Polynesia, in: Watabe, S., Maeyama, K., Nagasawa, H. (Eds.), Recent Advances in Pearl Research. TERRAPUB, pp. 183-195.

Helm, M.M., Trueman, E.R., 1967. The effect of exposure on the heart rate of the mussel, Mytilus edulis L. Comparative Biochemistry and Physiology 21, 171-177. https://doi.org/10.1016/0010-406X(67)90126-0

Higgins, P.J., 1980a. Effects of food availability on the valve movements and feeding behavior of juvenile Crassostrea viginica (Gmelin). I. Valve movements and periodic activity. Journal of Experimental Marine Biology and Ecology 48, 229-244.

Higgins, P.J., 1980b. EFFECTS OF FOOD AVAILABILITY ON THE VALVE MOVEMENTS AND FEEDING BEHAVIOR OF JUVENILE CRASSOSTREA VIRGINICA (Gmelin). 11. FEEDING RATES AND BEHAVIOR. Journal of Experimental Marine Biology and Ecology 46, 17-27. 
Jou, L.-J., Chen, B.-C., Chen, W.-Y., Liao, C.-M., 2016. Sensory determinants of valve rhythm dynamics provide in situ biodetection of copper in aquatic environments. Environmental Science and Pollution Research 23, 5374-5389. https://doi.org/10.1007/s11356-015-5735-5

Joubert, C., Linard, C., Le Moullac, G., Soyez, C., Saulnier, D., Teaniniuraitemoana, V., Ky, C.L., Gueguen, Y., 2014. Temperature and Food Influence Shell Growth and Mantle Gene Expression of Shell Matrix Proteins in the Pearl Oyster Pinctada margaritifera. PLoS ONE 9, e103944. https://doi.org/10.1371/journal.pone.0103944

Joubert, C., Piquemal, D., Marie, B., Manchon, L., Pierrat, F., Zanella-Cléon, I., Cochennec-Laureau, N., Gueguen, Y., Montagnani, C., 2010. Transcriptome and proteome analysis of Pinctada margaritifera calcifying mantle and shell: focus on biomineralization. BMC genomics 11, 613.

Le Luyer, J., Auffret, P., Quillien, V., Leclerc, N., Reisser, C., Vidal-Dupiol, J., Ky, C.-L., 2019. Whole transcriptome sequencing and biomineralization gene architecture associated with cultured pearl quality traits in the pearl oyster, Pinctada margaritifera. BMC Genomics 20. https://doi.org/10.1186/s12864-019-5443-5

Le Moullac, G., 2008. Adaptation du métabolisme respiratoire de l'huître creuse Crassostrea gigas (PhD thesis). Université de Caen Basse-Normandie, Caen.

Le Moullac, G., Schuck, L., Chabrier, S., Belliard, C., Lyonnard, P., Broustal, F., Soyez, C., Saulnier, D., Brahmi, C., Ky, C.-L., Beliaeff, B., 2018a. Influence of temperature and pearl rotation on biomineralization in the pearl oyster, Pinctada margaritifera. The Journal of Experimental Biology 221, jeb186858. https://doi.org/10.1242/jeb.186858

Le Moullac, G., Soyez, C., Ky, C.-L., 2018b. Low energy cost for cultured pearl formation in grafted chimeric Pinctada margaritifera. Scientific Reports 8. https://doi.org/10.1038/s41598-01825360-5

Le Moullac, G., Soyez, C., Latchere, O., Vidal-Dupiol, J., Fremery, J., Saulnier, D., Lo Yat, A., Belliard, C., Mazouni-Gaertner, N., Gueguen, Y., 2016a. Pinctada margaritifera responses to temperature and $\mathrm{pH}$ : Acclimation capabilities and physiological limits. Estuarine, Coastal and Shelf Science 182, 261-269. https://doi.org/10.1016/j.ecss.2016.04.011

Le Moullac, G., Soyez, C., Sham-Koua, M., Levy, P., Moriceau, J., Vonau, V., Maihota, M., Cochard, J.C., 2013. Feeding the pearl oyster Pinctada margaritifera during reproductive conditioning. Aquaculture Research 44, 404-411. https://doi.org/10.1111/j.1365-2109.2011.03045.x

Le Moullac, G., Soyez, C., Vidal-Dupiol, J., Belliard, C., Fievet, J., Sham Koua, M., Lo Yat, A., Saulnier, D., Gaertner-Mazouni, N., Gueguen, Y., 2016b. Impact of pCO2 on the energy, reproduction and growth of the shell of the pearl oyster Pinctada margaritifera. Estuarine, Coastal and Shelf Science 182, 274-282. https://doi.org/10.1016/j.ecss.2016.03.011

Nicholson, S., 2002. Ecophysiological aspects of cardiac activity in the subtropical mussel Perna viridis (L.) (Bivalvia: Mytilidae). Journal of Experimental Marine Biology and Ecology 267, 207-222. https://doi.org/10.1016/S0022-0981(01)00362-8

Pickens, P.E., 1965. Heart Rate of Mussels as a Function of Latitude, Intertidal Height, and Acclimation Temperature. Physiological Zoology 38, 390-405. https://doi.org/10.1086/physzool.38.4.30152416

Porter, E.T., Breitburg, D.L., 2016. Eastern oyster, Crassostrea virginica, valve gape behavior under diel-cycling hypoxia. Marine Biology 163. https://doi.org/10.1007/s00227-016-2980-1

Pouvreau, S., Rambeau, M., Cochard, J.C., Robert, R., 2006. Investigation of marine bivalve morphology by in vivo MR imaging: First anatomical results of a promising technique. Aquaculture 259, 415-423. https://doi.org/10.1016/j.aquaculture.2006.05.018

Rovero, F., Hughes, R.N., Chelazzi, G., 1999. Cardiac and behavioural responses of mussels to risk of predation by dogwhelks. Animal Behaviour 58, 707-714. https://doi.org/10.1006/anbe.1999.1176

Savina, M., Pouvreau, S., 2004. A comparative ecophysiological study of two infaunal filter-feeding bivalves: Paphia rhomboïdes and Glycymeris glycymeris. Aquaculture 239, 289-306. https://doi.org/10.1016/j.aquaculture.2004.05.029 
Shumway, S.E., Cucci, T.L., 1987. The effects of the toxic dinoflagellate Protogonyaulax tamarensis on the feeding and behaviour of bivalve molluscs. Aquatic Toxicology 10, 9-27.

Sow, M., Durrieu, G., Briollais, L., Ciret, P., Massabuau, J.-C., 2011. Water quality assessment by means of HFNI valvometry and high-frequency data modeling. Environmental Monitoring and Assessment 182, 155-170. https://doi.org/10.1007/s10661-010-1866-9

Stickle, W.B., Sabourin, T.D., 1979. Effects of salinity on the respiration and heart rate of the common mussel, Mytilus edulis L., and the black chiton, Katherina tunicata (Wood). Journal of Experimental Marine Biology and Ecology 41, 257-268. https://doi.org/10.1016/00220981(79)90135-7

Teaniniuraitemoana, V., Huvet, A., Levy, P., Gaertner-Mazouni, N., Gueguen, Y., Le Moullac, G., 2015. Molecular Signatures Discriminating the Male and the Female Sexual Pathways in the Pearl Oyster Pinctada margaritifera. PLOS ONE 10, e0122819. https://doi.org/10.1371/journal.pone.0122819

Teaniniuraitemoana, V., Huvet, A., Levy, P., Klopp, C., Lhuillier, E., Gaertner-Mazouni, N., Gueguen, Y., Le Moullac, G., 2014. Gonad transcriptome analysis of pearl oyster Pinctada margaritifera: identification of potential sex differentiation and sex determining genes. BMC genomics 15 , 491.

Uecker, M., Zhang, S., Voit, D., Karaus, A., Merboldt, K.-D., Frahm, J., 2010. Real-time MRI at a resolution of $20 \mathrm{~ms}$. NMR in Biomedicine 23, 986-994. https://doi.org/10.1002/nbm.1585

Vahirua-Lechat, I., Laure, F., LeCoz, J.R., Bianchini, J.P., Bellais, M., Le Moullac, G., 2008. Changes in fatty acid and sterol composition during oogenesis in the pearl oyster Pinctada margaritifera. Aquaculture Research 39, 1739-1746. https://doi.org/10.1111/j.1365-2109.2008.02050.x Wada, K., 1999. Formation and Quality of Pearls. Journal of Gemmological Society of Japan 20, 4762.

Wedderburn, J., McFadzen, I., Sanger, R.C., Beesley, A., Heath, C., Hornsby, M., Lowe, D., 2000. The Field Application of Cellular and Physiological Biomarkers, in the Mussel Mytilus edulis, in Conjunction with Early Life Stage Bioassays and Adult Histopathology. Marine Pollution Bulletin 40, 257-267. https://doi.org/10.1016/S0025-326X(99)00214-3

Zhang, S., Uecker, M., Voit, D., Frahm, J., 2010. Real-time MRI at 20 millisecond resolution. European Congress of Radiology. https://doi.org/10.1594/ecr2010/c-3415 
432 Figure 1: (a) the ecophysiological measurement system (EMS) for pearl oysters Pinctada margaritifera, biodeposits are harvested for analysis of organic matter assimilation; b) software interface showing the lights corresponding to the metabolic chamber being analyzed (b1), simultaneous measurements of dissolved oxygen and microalgae fluorescence (b2).

Figure 2: Overview of the magnetometer system. For data acquisition, a grafted pearl oyster Pinctada margaritifera is placed into the dome.

Figure 3 : Three-dimensional representation of the nucleus movement in two $P$. margaritifera pearl oysters. The circular motion observed on the left pearl corresponds to a pearl whose shape is not perfectly spherical rotating on an axis. The random movement observed on the right pearl corresponds to a perfectly spherical pearl. The temporal dynamics of pearl movement are revealed by the coloration of the line illustrating the movement. The color code is that of the rainbow, the beginning of the recording is marked by the color red

Figure 4: Continuous recording of the valve activity of a pearl oyster for 17 days.

Figure 5: Spectral analysis of the continuous recording of valve activity (a) spectrogram revealing a major peak of activity at $23.25 \mathrm{~h}$, (b) series enlargement showing high frequency micromovements.

Figure 6 : Schematic pearl oyster whose valve opening is likened to a right-angled triangle where is the opening angle at the hinge, $\mathrm{L}$ : the length of the shell, $\mathrm{H}$ : the valve spread value opposite the hinge. 
457

458

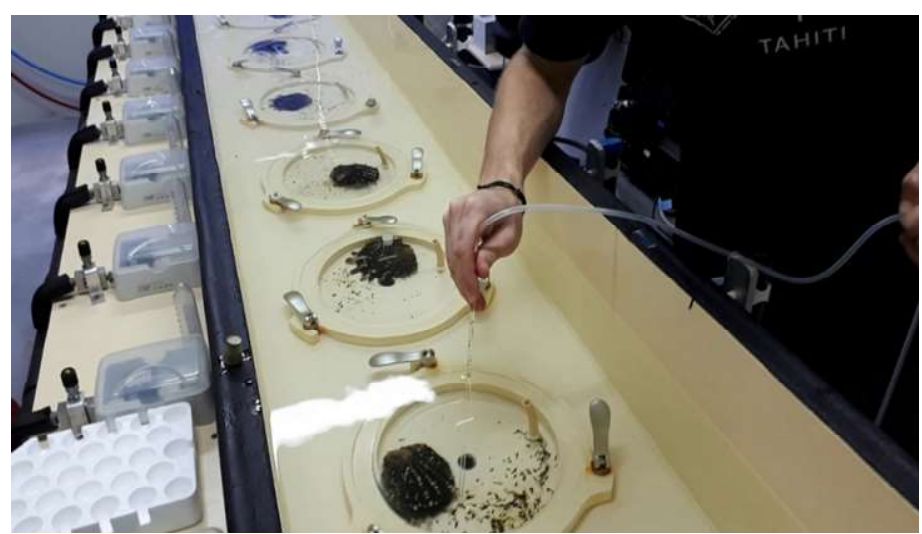

Figure 1

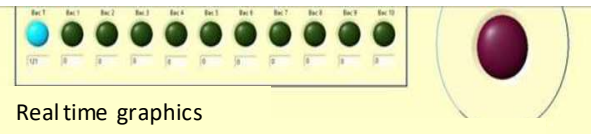

oxygen

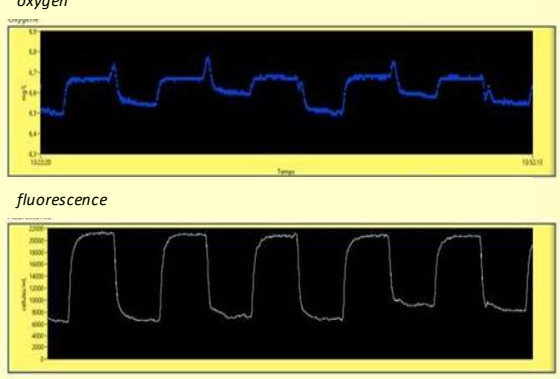

459 


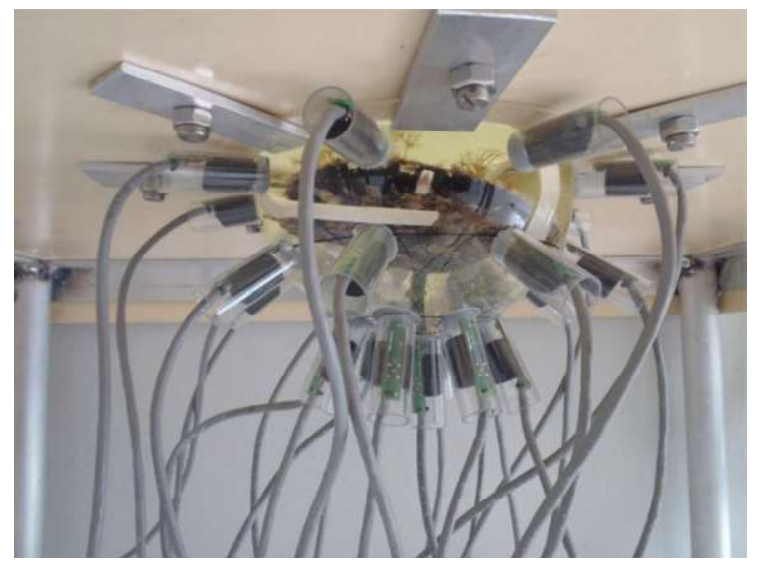

Figure 2
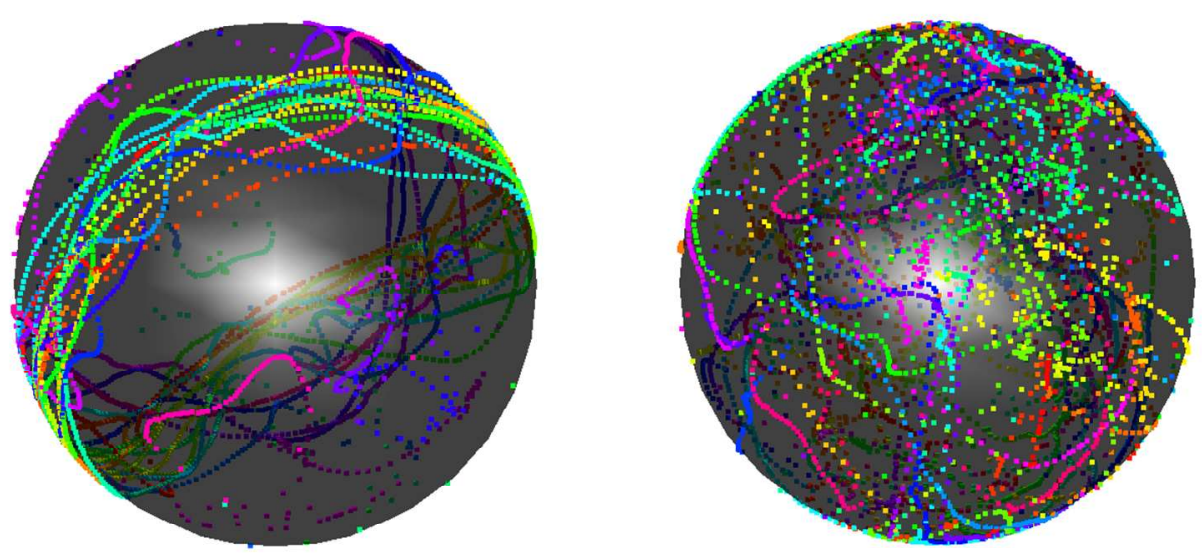

Figure 3 


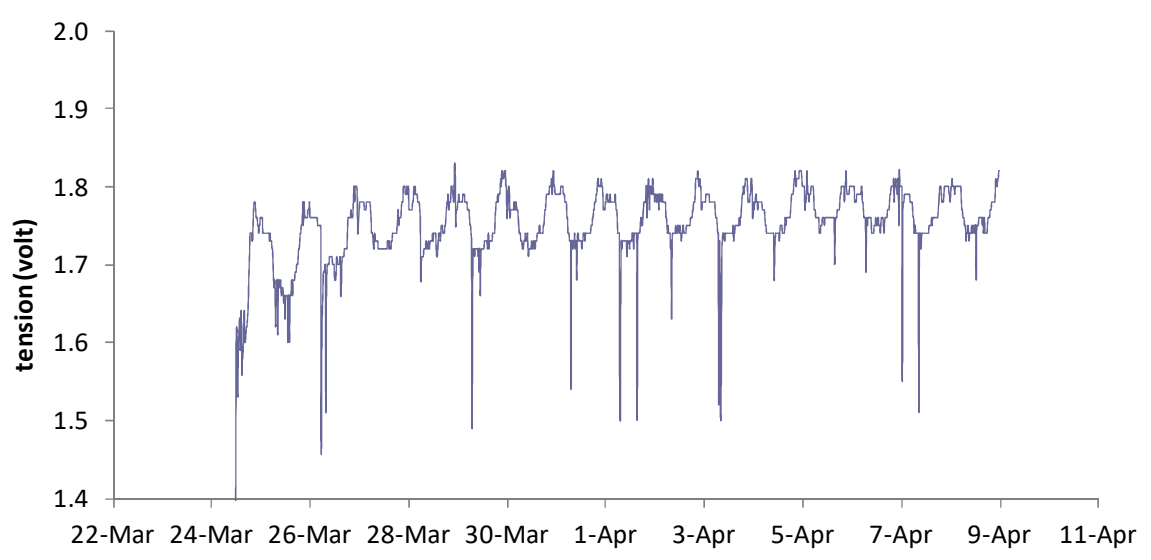

Figure 4
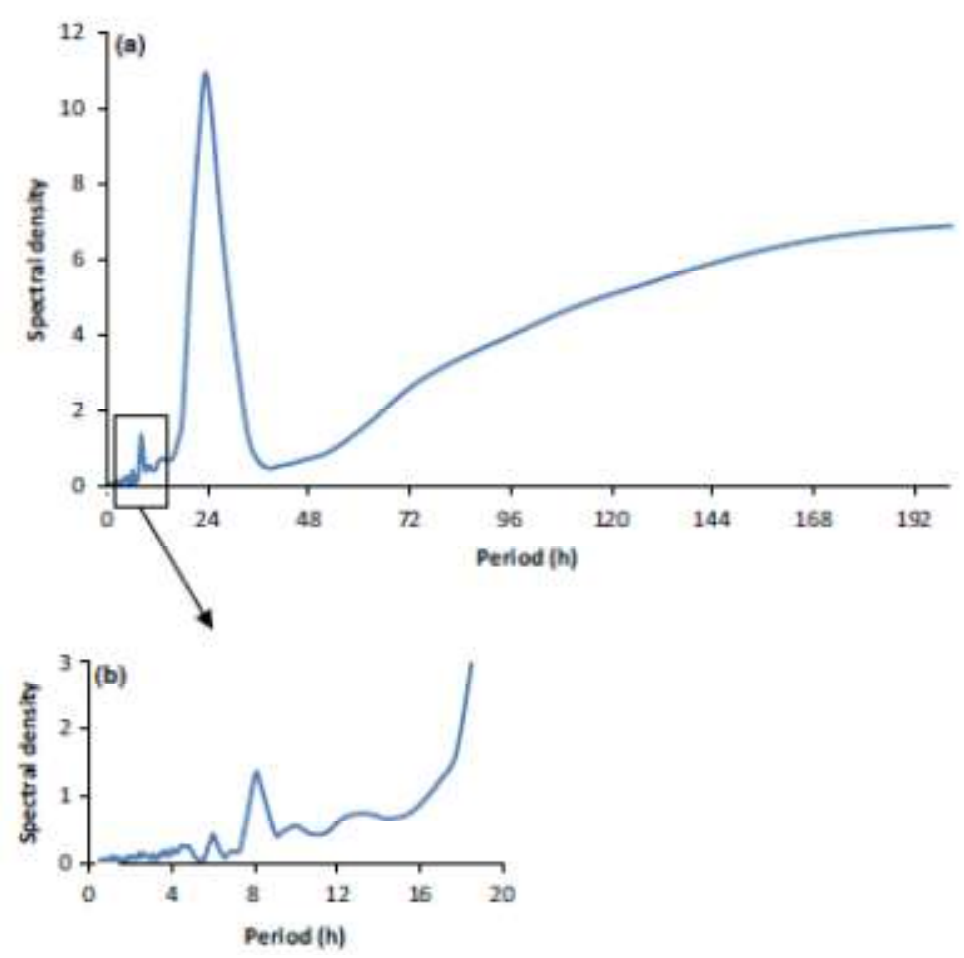

Figure 5 


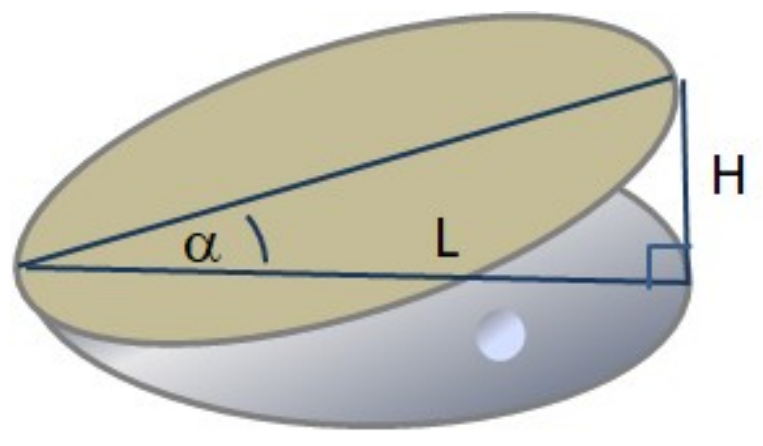

487

Figure 6

488 